\title{
O DEBATE A RESPEITO DOS OGM NA INTERNET: ENTRE A FALA CIDADÃ E A FALA CIENTÍFICA
}

\author{
F. Cusin-Berche \\ F. Mourlhon-Dallies
}

\begin{abstract}
Resumo
Este artigo trata da discussão empreendida no grupo "fr.sci.divers", sobre a questāo do milho transgênico e dos organismos geneticamente modificados (OGM). O corpus analisado constitui-se das mensagens trocadas pelo grupo, cujo debate se desenrola sobre questões relativas à ciência e aos acontecimentos científicos. A análise vai levar em consideração os "lugares enunciativos" construídos pelo discurso dos internautas, os quais estāo definidos pelos autores a partir de duas "comunidades discursivas": aquela dos especialistas c a dos não especialistas.
\end{abstract}

De novembro de 1997 a janeiro de 1998 o debate sobre a questão do milho transgênico e dos organismos geneticamente modificados (OGM) estava no seu auge, na internet, no grupo de discussão "fr.sci.divers". Uma centena de mensagens pode ser coletada e analisada, constituindo um primeiro passo no estudo das interações mediadas por computador, centradas em acontecimentos político-científicos.

Como indica o adjetivo "diversos" no "fr.sci.divers", o grupo de discussão de onde o corpus é tirado constitui um espaço aberto de troca onde são tratadas variadas questões relativas à ciência e aos acontecimentos científicos. A discussão sobre o milho transgênico era contígua, entre outras, com discussões sobre as propriedades da borracha não vulcanizada, sobre as células fotovoltaicas, sobre as crateras de meteoritos ou sobre o efeito estilingue na astronáutica, sem esquecer um debate sobre as relações entre ciência e religião e toda uma série de considerações técnicas sobre a forma de 
fabricação de si-mesmo como se fosse uma mera espécie de massa de modelar. Para o período considerado, constatamos, no entanto, que o debate sobre os OGM ocupou a frente da cena com uma rara intensidade, ao ponto de concernir um quarto das mensagens $^{1}$ trocadas no "fr.sci.divers".

Nas mensagens consagradas aos OGM, os outros assuntos abordados no "fr.sci.divers" apareciam pouco; não encontramos senão algumas alusões, por exemplo, ao debate sobre as religiões e a ciência, relativas à seita Raël. ${ }^{2}$

De: @news.ens.fr

Data: 07/12/1997

>> O que diz Raël sobre o milho transgênico?

$>$

Eu nunca li nem entendi nada dele à esse respeito. > Por que? Bem, supostamente, sua mensagem devia aliviar o mundo, né? Com tantas brigas sobre milho transgênico rolando no newsgroup, achei que o mínimo que esse Raël podia fazer era nos dar uma dica a respeito.

Fora duas ou três interferências deste gênero, ${ }^{3}$ o debate sobre os OGM é por assim dizer alimentado por uma série de trocas vigorosas, às vezes virulentas, se desenrolando freqüentemente sobre períodos muito curtos. O corpus tem, deste modo, a rapidez de

${ }^{1}$ Nosso corpus é composto precisamente de 97 mensagens de diversas extensões, provenientes de 40 interlocutores diferentes.

${ }^{2}$ Nenhuma modificação ortográfica foi feita nas mensagens originais citadas ao longo deste artigo, entretanto retiramos o início dos endereços eletrônicos, de modo a proteger o anonimato dos internautas. Nós destacamos aos leitores não familiarizados com as mensagens eletrônicas que os símbolos "maior" (>) servem para dissociar as diversas trocas. Por exemplo, no fragmento citado, o enunciado que figura em primeiro é precedido de dois símbolos "maior" (>); trata-se, portanto, da primeira mensagem emitida por Ll, o segundo enunciado não é assinalado senão por um símbolo "maior", isso corresponde à resposta dada por um outro locutor (L2), o texto que segue não é munido desse símbolo, trata-se da última intervenção de L1. Se tivessem ocorrido quatro intervençōes sucessivas, a primeira teria sido assinalada por três símbolos "maior", e assim por diante.

${ }^{3}$ Algumas indicações sobre a utilização do suporte internet (outros fóruns, problemas técnicos) emergem de tempos em tempos. Em relação ao tema central, é igualmente uma questão da energia nuclear, da segurança aérea, da confiabilidade das teorias científicas e dos mecanismos de decisões políticas.

Rua, Campinas, 9: 47-68, 2003 
uma discussão descontínua, mais dura, tanto que nenhum moderador regula nem filtra as trocas do grupo "fr.sci.divers".

Trata-se, portanto, de um exemplo de comunicação mediada por computador, isto é, sem mediador científico nem jornalista, ${ }^{4}$ que decidiria os contornos da fala e asseguraria a coerência dos temas abordados. A discussão organiza-se sem terceira pessoa. Eis aí uma diferença fundamental com os suportes em "papel" (revistas, jornais), na medida em que a publicação de escritos é sempre o fruto de escolhas antecipadas e de reescritura, de seleção, de encenação da fala do outro (mesmo quando as entrevistas se pretendem fiéis e as cartas de leitores espontâneas); da mesma maneira são os Jornais Televisionados ${ }^{5}$ que supõem uma regulação das falas e uma orquestração da expositio.

Sobre o grupo de discussão "fr.sci.divers", podemos afirmar que nenhuma censura é praticada e que cada um que intervém fala em seu próprio nome, em total liberdade. A ausência de encenação institucional incita os protagonistas a atribuir um papel a si mesmos, a construir uma identidade para si, a partir de elementos diversos (e mesmo de artefatos) peritextuais, discursivos e lingüísticos que nós procuraremos mostrar. Isso significa que nós nos interessamos por todos os traços constitutivos do posicionamento dos locutores, e - ainda que nos encontremos em face de discursos reportados ${ }^{6}$ e não em face de discursos transportados - pelos "lugares enunciativos que o discurso constrói, através de representações que ele dá ao discurso dos outros". (Moirand, 1998)

Nós consideramos, para uma primeira abordagem, que no debate sobre os OGM duas comunidades ${ }^{7}$ discursivas intervêm:

\footnotetext{
4 " Por mediador entendemos aqui uma entidade teórica (instituição + sujeições editoriais + jornalistas) que se atualiza na materialidade textual sobre diferentes construções enunciativas." (Moirand, neste número). ${ }^{5}$ Cl. Petiot e Battestini-Drout.

"Nós forjamos este sintagma (F. Cusin-Berche, 1999: 34) para dar conta da situação interativa particular criada pela mediação eletrônica que permite inserir uma resposta no seio do espaço textual da mensagem de origem.

7"Os rituais linguageiros definem comunidades que não são isoladas sobre bases étnicas/lingüísticas, mas por práticas linguageiras partilhadas ou reconhecíveis." (Beacco, 1992:11)
}

Rua, Campinas, 9: 47-68, 2003 
- pesquisadores, biólogos ou virologistas, que talvez os jornalistas qualificariam como especialistas ou experts $s^{8}$ científicos, mas que não se denominam eles mesmos "experts", ainda que esses locutores ostentem nas suas mensagens argumentos de natureza científica, dos quais eles se prevalecem para se sobressair no debate;

- não especialistas, que assistem, sem poder argumentar no mesmo nível neste debate científico e que procuram deslocá-lo para um outro terreno, aquele do saber dos alimentos, da cidadania, da economia, ou do humanitário.

Assim partimos da hipótese de que estamos frente a duas "falas", uma fala científica e uma fala cidadã, das quais examinaremos as manifestações diferenciais constitutivas. Esta bipartição constitui um dos principais jogos a partir do qual o debate se estrutura, pois nós temos, de um lado, os detentores da "fala científica" que negam aos outros a capacidade de raciocinar (irracional é empregado em várias retomadas para estigmatizar a atitude dos não especialistas), e, de outro lado, os representantes da "fala cidadã" que não param de desestabilizar a autoridade, às vezes marcada por uma certa arrogância, dos primeiros.

Em busca de elementos que permitem identificar os internautas presentes, constatamos que a construção identitária se efetua em três níveis: peritextual," paratextual e discursivo.

\section{A identidade eletrônica ou identidade "imposta"}

Antes mesmo de ler o corpo das mensagens, descobrimos, primeiramente, os dados peritextuais: ${ }^{10}$ o nome e o endereço eletrônico do internauta, no alto à esquerda do texto. Essas indicações constituem uma "identidade eletrônica" da qual o enunciador da mensagem não pode, em princípio, escapar, ao contrário, por exemplo, da assinatura que ilustra uma escolha operada pelo locutor: é por isso que falamos de identidade

\footnotetext{
* Cf. Petit.
}

"Utilizamos, aqui, a distinção feita por G. Genette (1982), que chama de peritexto os elementos do paratexto que são inseparáveis do texto, e nós destinamos esta denominação às rubricas identitárias predeterminadas pelo logicial utilizado. Reservamos o termo paratexto à designação de elementos similares, por exemplo, a assinatura, que se apresenta como integrada ao texto.

${ }^{10}$ Para uma representação mais completa do procedimento geral das mensagens trocadas na internet nos reportaremos a F. Mourlhon-Dallies e J. - Y. Colin (1995). 
imposta, mesmo sabendo muito bem que basta ser especialista em internet para truncar ou modificar um endereço eletrônico, ou ainda obter um a partir de um pseudônimo. "

Graças a essas mediações epigráficas, constatamos no "fr.sci.divers" que a maior parte das conexões se efetuam de lugares de trabalho (Instituto Pasteur, Instituto Curie, CNRS, universidades científicas diversas ${ }^{12}$ ) cujo prestígio científico é internacional. Os endereços de emissão já conotam um certo nível de conhecimento ligado à ancoragem institucional, que se encontra freqüentemente confirmada pelo conteúdo das mensagens trocadas: como testemunham os exemplos abaixo emitidos respectivamente a partir da Universidade de Strasburgo e do CNRS:

De: @ chouchen.u-strasbg.fr>

Data: 05/12/1997

Outros cientistas, a maior parte médicos (desolados por eles) aliaram-se ao dogma da barreira interespecífica, porque eles pensavam em uma origem viral. A proteína príon isolada na época não era para eles senão uma proteína de um vírus que eles tentaram isolar em vão.

Quanto às doenças complexas ao vírus, transportando o DNA, se um tal acontecimento fosse possível, a cultura intensiva do milho há dois séculos, num meio ambiente artificial para ele, teria permitido ver aparecer este raro acontecimento.

De: @isv.cnrs-gif.fr

Data: 01/12/1997

Os primeiros casos de resistência à proteína tóxica ativa sobre as larvas de insetos estão descritas. Mas isso não está ligado aos OGM (estes vindo aparecer nos cam-

\footnotetext{
"Este gênero de manipulaçāo já é produzido: só um outro especialista de internet pode detectar a fraude. ${ }^{12}$ Especialmente, a de Nice e a de Strasburgo, mas também estabelecimentos de prestígio como o INRA (Instituto Nacional de Pesquisa Agronômica), o CEA (Centro de Estudo Atômico), a Escola Politécnica e o ENS (Escola Nacional Superior).
} 
pos) [...] Na biologia, tudo é uma questão de equilíbrio e de regulação, e a variabilidade dos organismos vivos é tal que nenhuma proteção ou resistência pode ser considerada como absoluta...

Em conseqüência da ausência de um mediador apoiando-se nas qualidades de uns ou de outros, esses endereços institucionais funcionam como rótulos de cientificidade. Eles são com toda evidência lidos pelos internautas, como testemunha a reação à mensagem emitida por um estudante da Escola Normal Superior, na qual nós criticamos uma certa pretensão:

De: @worldnet.fr>

Data: 04/12/1997

[Nome Sobrenome] escreveu:

$>$ Mas meu bom senhor, eu espero que você não coma $>$ *JAMAIS* maçãs

$>$ compradas num supermercado qualquer, e sobretudo no seu $>$ vizinho

$>$ produtor, mas unicamente aquelas do pomar que você

$>$ plantou no seu jardim. Porque imagine você que os $>$ pomares não são naturais, isso não, eles são *implantados*, > você se dá conta!

Mas minha querida senhora, não é porque você estuda nos bancos da escola e porque você aprendeu ontem o que era um implante que é preciso tomar todos os outros participantes do debate por ignorantes...

Você se engana de debate.

Sobre esta "fome", eu deixo você com seus Hamburgueres.

Apesar da interpelação um pouco paternalista ("mas meu bom senhor"), o tom adotado por esta jovem não é mais condescendente que aquele dos outros que intervêm, mas o endereço eletrônico - assinalando um estatuto estudantil (eleves.ens.fr), por um lado, e, por outro, revelando um nome feminino - desencadeou visivelmente reações epidérmicas.

O endereço eletrônico pode, portanto, se tornar um ponto de cristalização dos preconceitos e das representações sociais, de forma que alguns internautas, conscientes

Rua. Campinas, 9: 47-68, 2003 
desta "rubrica" automática, funcionam sobre dois registros: eles reinscrevem seu endereço sob a assinatura, em seguida precisam que seus propósitos são estritamente pessoais.

De: @ensam.inra.fr>

Data: 28/11/1997

Os riscos existem em três níveis na transferência de genes.

- disseminação de resistências aos antibióticos. Essas resistências fazem parte dos crivos utilizados para selecionar os transformantes (o Agrobacterium Tumefaciens tem o plasmídeo transformante).

- disseminação de resistências aos herbicidas, igualmente utilizados de maneira geral como crivo das plantas transformadas.

- toxicidade eventual da substância produzida graças ao gene introduzido. (Parece que este não é o caso da toxina Bacillus introduzida no milho).

[Nome Sobrenome], Montpellier

@ ensam.inra.fr

propósitos estritamente pessoais

Assim, na maior parte dos casos, a identidade eletrônica revelada pelos endereços é sublinhada pelos autores das mensagens quando eles pertencem a estabelecimentos científicos, de maneira a reforçar sua autoridade no debate. Alguns internautas se definem, aliás, não somente através de sua ancoragem institucional, mas também pelo seu pertencimento disciplinar a fim de fazer prevalecer seu ponto de vista.

\section{A identidade (para)textual ou identidade "clamada"}

Além da incontornável identidade eletrônica (peritextual) que lhes é imposta, alguns internautas escolheram inserir no fim de sua mensagem uma assinatura datilo- 
grafada ou uma assinatura automática, ${ }^{13}$ que pode ser redundante (se ela não contém senão o nome e/ou o sobrenome), mas que lhes permite se definir como entendem. Alguns a utilizam para fornecer precisões sobre suas implantações geográficas e/ou sobre suas atividades profissionais, mas elas testemunham igualmente o posicionamento que cada um reivindica no debate. Assim, as assinaturas reduzidas ao nome figuram apelidos afetuosos (Tom, Phil etc.). Essas indicações paratextuais têm por função solidificar, e também sustentar, os dizeres:

De: @iprolink.ch>

Data: 08/12/1997

No caso que nos interessa, a passagem de um gene hospedeiro do vírus (nessa circunstância, o gene acrescentado no milho transgênico), é preciso que um erro de replicação do DNA (ou ARN) viral integre um pedaço do DNA (ou do ARN) celular. $\mathrm{O}$ vírus é um organismo muito pequeno que encapsula ao máximo seu material em seu invólucro. Um pedaço suplementar torna o DNA difícil de encapsular, e é por isso que a probabilidade é muito fraca. A operação é possível, por exemplo removendo um pedáço do vírus pouco útil e substituindo-o por um outro gene (é realizado em laboratório, especialmente com os Poxvírus (Vaccinia)que têm um material genético relativamente complexo).

Aparentemente, eu ainda tenho algumas lembranças de meus cursos de virologia...;) [Nome Sobrenome], Biólogo

A conservação de uma "assinatura automática" de caráter institucional no final da mensagem, integra mais discretamente, mas não com menos eficácia, a construção desta autoridade "científica":

1s . O dispositivo de assinatura automática dá um estatuto particular àquilo que chamamos assinatura datilografada, com efeito esta última não tem, contrariamente à assinatura manuscrita, valor de autenticação, além disso, ela não tem função informativa já que a assinatura automática é habitualmente mais completa." (Cusin-Berche, 1999)

Rua, Campinas, 9: 47-68, 2003 
De: @ chouchen.u-strasbg.fr

Data: 01/12/1997

Restant: [...]o problema de estocagem do herbicida (glyphosate) pela planta é ainda sujeito à caução (no momento, eu não vi publicações senão do fabricante Monsanto sobre esse problema e nem estudos independentes).

François.

INome Sobrenome / grupo de bioinformática /bioinformatics groupe tel:(+33) 388653271 / IGBMC BP 16367404 Illkirch France

Conforme alguns exemplos precedentes, é freqüente que aqueles que intervêm precisem seu pertencimento disciplinar logo em seguida de sua assinatura.

Trata-se de persuadir, mais que de convencer, os interlocutores que se sabe do que se fala, a identidade institucional e disciplinar tendo valor de legitimação. Entretanto, este recurso implícito ao princípio de autoridade ${ }^{14}$ não escapa a certos "debatedores" que não hesitam em lhe tornar derrisório. É assim que aparecem em nosso corpus dois exemplos de identidades fantasistas abertamente marcadas pela ironia.

De: @pipo.com>

Data: 28/11/1997

Nós somos 6 milhões aqui. Esta porcentagem deve ser ponto de partida de toda reflexão a propósito das novas tecnologias agronômicas.

$[\ldots]$

[Sobrenome],

bioquímico incompetente e agrônomo por erro.

14 "O argumento e autoridade é o modo de argumentação retórica que foi muito vivamente atacado porque, nos meios hostis à livre pesquisa científica, ele foi utilizado e isso de maneira abusiva, peremptória. isto é, dando-lhe um valor constrangedor, como se as autoridades invocadas tivessem sido infalíveis." (Perelman e Olbrechts-Tyteca, 1992: 411)

Rua, Campinas, 9: 47-68, 2003 
Trata-se de um novato que parodia as assinaturas "científicas" ou de um científico que zomba das pretensões de seus parceiros? Dois índices concorrem em favor da segunda interpretação: de um lado o qualificativo "incompetente" não invalida o pertencimento disciplinar, já que se trata de um avaliativo, neste caso, autodesvalorizante; de outro lado a precisão "por erro" levando aos acasos da vida implica que a pessoa seja efetivamente agrônoma, condição sine qua non para que tenha havido "erro". Estes enunciados parecem dessa forma revelar mais a denegação ${ }^{15}$ do que a negação, embora, no registro da derrisão, o locutor citado abaixo explore mais claramente a provocação:

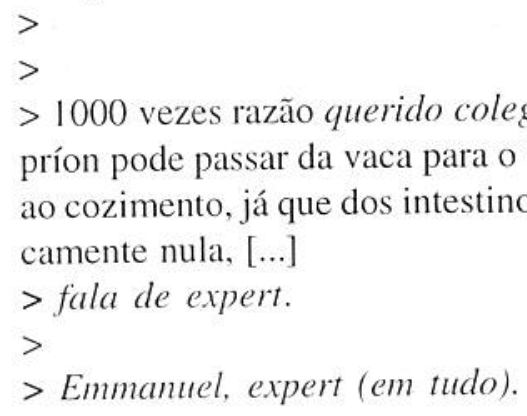
camente nula, $[\ldots]$

$>$ fala de expert.

$>$

$>$ Emmanuel, expert (em tudo). príon pode passar da vaca para o homem, $>$ seria preciso primeiro que ele resistisse ao cozimento, já que dos intestinos ele passa para o sangue. A probabilidade é prati-

A menção "em tudo", valorizada paradoxalmente pelo uso dos parênteses, se inscreve em contradição com a representação estereotipada do expert que entendemos como um especialista de um domínio e não como um generalista. Assim podemos interpretar esta precisão de valor "oximoro" como marca de ironia para com os científicos que indicam suas especialidades. Embora a apelação "querido colega" e a natureza do propósito sejam suscetíveis de sugerir que este Emanuel não é ignorante no assunto.

\footnotetext{
${ }^{15}$ No sentido psicanalítico do termo.
} 
A forma com que os internautas se definem parece seguir as circunvoluções da discussão, como o ilustra a evolução das assinaturas. Por exemplo, um mesmo internauta particularmente prolixo no seio do corpus apresenta seus argumentos científicos com segurança e assina alternativamente: seu nome seguido de seu sobrenome, ${ }^{16}$ ou acrescenta a menção "Biólogo", ${ }^{17}$ ou ainda faz seguir seu nome e sobrenome de "Biólogo, Suiço", ${ }^{18}$ ou ainda não assina. ${ }^{19}$ A partir desses dados iniciais aparecem algumas variantes: o nome seguido da ancoragem disciplinar e da nacionalidade, ${ }^{20}$ ou ainda o nome abreviado sob forma de apelido seguido de "Biólogo, Suíço". ${ }^{21}$

De: @iprolink.ch>

Data: 01/12/1997

Eu vi os Guignols que fizeram uma "news" sobre isso e que reflete bem o medo injustificado das pessoas: milho geneticamente modificado = se nós o comemos vamos ser também geneticamente modificados!!

$[\ldots]$

Portanto eu repito para aqueles que não compreenderam. Todos os dias comemos legumes que contêm quantidade de genes, ninguém se tornou verde por ter ingerido genes da clorofila!

Phil, Biólogo, Suíço

Quando se coloca no plano da cidadania evocando outras transações ele não intervém mais como biólogo, mas como Suíço:22

16 (348BFI 1B.7C8F@iprolink.ch)

17 (348BCA7B.2062@iprolink)

18 (3486D098.6687@iprolink.ch e 347EFCE2.4CB1@iprolink.ch)

14 (3486D320.2CA3@iprolink.ch)

20(34852D5D.577D@iprolink.ch)

21 (3482D2BD.484A@iprolink.ch e 3482A54B.489D@iprolink.ch)

22 (3487FAA6.71CE@ipprolink.ch)e (34869 68.7 CE7@iprolink) 
De: @iprolink.ch>

Date: 05/12/1997

Eu estou na Suiça, o país mais afetado por este problema, e eu continuo a comer carne. Eu acho que o risco é pequeno. É preciso correr riscos na vida! Aliás o ser humano passa seu tempo a correr riscos, né?

[Nome Sobrenome], Suiço

Quando ele desestabiliza seu próprio terreno de biólogo, a menção profissional desaparece de sua assinatura que se resume à "Phil, Suíço". ${ }^{23}$

De: @iprolink.ch>

Data: 01/12/1997

Por qual mecanismo o gene uma vez nas células vegetais passaria às células bacterianas? A resistência aos antibióticos passa de bactéria à bactéria (e aliás não necessariamente da mesma espécie): mas por qual mecanismo ela pode passar do milho a uma bactéria? Em princípio o gene não é nem expresso, não é? Há talvez alguma coisa na qual eu não tenha pensado, se alguém tem a resposta.

Phil, Suíço

As assinaturas, lugar de afirmação de si, são também áreas estratégicas de questionamento ou de afirmação da autoridade e do saber.

Entretanto, as atribuições ou as reivindicações identitárias não concernem somente às últimas linhas das mensagens correspondendo às assinaturas, elas podem ser objeto de um debate no coração das mensagens:

${ }^{23}$ (3482D21C.7D2F@iprolink)

Rua, Campinas, 9: 47-68, 2003 
De: @clio.unice.fr

Data: 28/12/1997

$>$ Eis os ecologistas insatisfeitos que se restabelecem;-)

$>$ É de novo uma reação epidérmica não sustentada $>$ cientificamente $>$ que joga sobre o medo das pessoas.

Eu não sou nem ecologista (nenhum ecologista aliás sustentaria este discurso: o antiestatismo não é uma característica flagrante nos criados zelosos) nem biólogo, nem gosto de reclamar à toa, mas se há algo epidérmico nesta mensagem, é justamente no fato dela ter sido publicada no próprio dia em que a decisão foi tomada.

Percebemos, assim, que no curso das trocas a imagem dada de si se afina e se diversifica, através desta identidade "clamada" que pode ser construída a partir de critérios ideológicos, psicológicos ou disciplinares e mesmo às vezes geográficos. Acontece às vezes que o duelo entre cientistas e cidadãos se adoça, permitindo a reaproximação de protagonistas a pontos de vista diferentes. É assim, por exemplo, que dois biólogos vão se declarar gastrônomos, um assinando: "François, biólogo e amante de produtos bio...", o outro em resposta a um não especialista:

De: @iprolink.ch>

Data: 01/12/1997

$>$ Bem, o que eu disse: eu não sou > biólogo...... somente $>$ amante das boas comidas (e de bons vinhos).

Eu sou biólogo E amante de boa comida e de bons vinhos, não é contraditório! Eu penso que a contradição é mais no nível do rendimento: é difícil ser amante de produto de qualidade e de bom vinho sendo pobre. Né? (quando eu vejo o preço do Bordeaux 95, eu não posso senão pensar isso ;-)

Phil, Biólogo, Suíço 
Esta declaração de fé pode ser considerada como uma penetração no terreno do contradito para fazer aceitar melhor seu ponto de vista; ele não fica neste terreno a não ser acumulando duas identidades em função das quais "cidadãos" e "cientistas" se tinham definido, ele despossui seu interlocutor de sua especificidade. Manobra de sedução ou ímpeto de simpatia apesar dos desacordos, este desdobramento identitário mostra a inconstância do debate, já que o especialista pode intervir enquanto cidadão, retomar a seu favor os valores cidadãos, embora o cidadão esteja isolado na sua própria esfera.

Trabalhando assim sua encenação, ${ }^{24}$ alguns internautas chegaram a um estatuto particular. Na medida em que o debate se amplia, cada um se atribui um papel que será assimilável ao "biólogo de serviço", ao "amante de boas carnes" ou ainda ao "desmancha-prazeres". Esses personagens se tornam, de algum modo, "figuras" da rede, que têm tendência a monopolizar a fala pela produção de um grande número de mensagens.

\section{A identidade discursiva}

Aqueles que falam se revelam também através de seu discurso, e as identidades "clamadas" podem ser confrontadas ao que nós escolhemos considerar como marcas relativas à identidade dos internautas, apoiando-nos sobre alguns indícios lexicais e discursivos marcados nas mensagens.

Entre os indícios de especialização científica notaremos no plano sintático o emprego do presente gnômico assim como o predomínio, no corpo da mensagem, de construções que impessoalizam pelo recurso a sujeitos não humanos; e observaremos sobre o plano lexical o uso de uma terminologia especializada, valorizada pelas reformulações colocadas entre parênteses ou pelas aspas, a qual supõe uma forte cultura científica no assunto:

${ }^{24}$ Cujas formas gerais são abordadas em F. Mourlhon-Dallies e J.-Y. Colin, 1999.

Rua, Campinas, 9: 47-68, 2003 
De: @iprolink.ch>

Data: 08/12/1997

No caso que nos interessa, passagem de um gene hospedeiro ao vírus (nessa circunstância, o gene acrescentado no milho transgênico), é preciso que um erro de replicação do DNA (ou $A R N$ ) viral integre um pedaço do DNA (ou do ARN) celular. O vírus é um organismo muito pequeno que "encapsula" ao máximo seu material genético em seu invólucro. Um pedaço suplementar torna o DNA difícil de encapsular, e é por isso que a probabilidade é muito fraca. A operação é possível, por exemplo removendo um pedaço do vírus pouco útil e substituindo-o por um outro gene (é realizado em laboratório, especialmente com os Poxvírus (Vaccinia) que têm um material genético relativamente complexo).

Aparentemente, eu ainda tenho algumas lembranças de meus cursos de virologia... ;-) [Nome Sobrenome], Biólogo

Neste exemplo, as reformulações de tipo sinonímia pertencendo igualmente ao registro técnico não são destinadas a esclarecer o interlocutor novato, mas teriam por função colocar em excerto os conhecimentos adquiridos, como o destaca o comentário de auto-satisfação que precede a assinatura. Assim podemos considerar que neste caso identidade clamada e identidade discursiva coincidem, embora outros locutores, aparentemente "sábios", não reivindiquem explicitamente um estatuto de científico. A espontaneidade (sem artefato tipográfico) com a qual alguns utilizam termos especializados ou grupos terminológicos testemunha seus conhecimentos, um conhecimento que se exprime também na sua atitude em fornecer explicações de ordem técnica:

De: @curie.fr

Data: 08/12/1997

Eu concordo que a exportação do gene de "resistência" à pérale* é um risco mínimo, haja vista a extensão da estrutura genômica a exportar: o risco é portanto ínfimo.

* N.T.: Inseto lepidóptero nocivo às verduras. 
Entretanto, a capacidade de empacotamento de algum vírus não é tão negligenciável assim. É aliás um vetor muito utilizado em pesquisa para expressar genes onde não se exprimem (eu explicarei tudo se vocês o desejarem).

O risco do qual eu falo é aquele da exportação do gene marcador da seleção: o gene da enzima béta-lactamase (não muito grande como gene!!), acarretando, se eu não abuso, uma resistência à ampicilina (eu me engano, talvez, antibiótico).

Tom

Se a explicação "pressupõe uma assimetria dos lugares interacionais, que corresponderia a uma assimetria dos conhecimentos" (Moirand, 1999), sua presença neste gênero de debate reaproxima o autor da "fala científica". Da mesma maneira, a organização do discurso pode refletir uma atitude de caráter científico: interrogação sugestiva, recusa argumentada apoiando-se em princípios teóricos reconhecidos (irrecusáveis?) e formulação de hipótese.

De: @-PAS DE PUB SVP-hol.fr

Data: 04/12/1997

O que você diz que as modificações genéticas pela implantação direta de um novo gene não vão acarretar danos. Certamente devemos fazer experiências mas a improvisação do DNA me parece bem mais nova que o cruzamento das espécies, que mesmo se ele volte a mudar o DNA, isso se faz unicamente se há COMPATIBILIDADE. Ora a introdução direta de um gene num DNA qualquer permite curtocircuitar a compatibilidade. Entretanto, esta compatibilidade que os partidários das manipulações genéticas gostam de nos lembrar em alto e bom som quando se trata de falar de dispersão do novo gene para outras espécies, esta incompatibilidade não pode ser uma segurança?

Em geral, esta atitude de entrar no debate é correlata à identidade institucional dos interventores conectados dos laboratórios de pesquisa que usufruem um renome certo no assunto.

Rua. Campinas, 9: 47-68, 2003 
O fosso entre os cientistas e os outros se marca, portanto, no debate, não somente peri/paratextualmente, mas ainda intratextualmente, isto é, através da materialidade discursiva e lingüística. Este afastamento torna-se o objeto de um jogo de poder entre os que detêm conhecimentos e os que não sabem. Assim, em nome da ignorância científi$\mathrm{ca}$, prestada uns para os outros, estes últimos negam aos primeiros o direito à fala, a edificação de uma fronteira "fala científica" e "fala cidadã" desloca o debate para um outro terreno.

Serve de revelador em relação a isto o grande número de unidades lexicais marcando o campo semântico do saber e da ignorância, tanto nos propósitos científicos:

De: @curie.fr

Data: Fri, 02 Jan 1998 10:23:47 +0100

Organização: Instituto Curie - Seção de Pesquisa

Parece-me que a maioria dos franceses não tem as competências científicas necessárias para fazer a parte das coisas neste assunto.

A maior parte não tem sempre razão. Enfim, me parece!

Tom

De: @ news.ens.fr

Data: 03/12/1997

Ah, nós tínhamos constatado... No teu lugar, eu evitaria me exaltar demais de minha ignorância, (pessoalmente, eu prefiro escondê-la). É raramente um sinal de abertura de espírito.

... quanto nos não-científicos que são suscetíveis de reconhecer sua ignorância sem verdadeiramente escandalizar-se com ela, e que manifestam uma ponta de irritação em relação aos "sábios":

Rua, Campinas, 9: 47-68, 2003 
De: @ wanadoo.fr

Data: 03/12/1997

O trigo "natural", assim como crescia na natureza, não "resistia": impossível colhê-lo, seus grãos caíam ao vento, ou a toda manipulação. E uma vez que tínhamos enfim conseguido juntar um pouco, na melhor das hipóteses fazíamos bolos. E mais, eu acredito que o trigo que servia para fazer bolos era já um trigo nascido de cruzamentos devido aos Egípcios. Geneticamente modificados portanto. Eu estou longe de ser um especialista, que me perdoem portanto de me satisfazer com explicações "gerais" ou aproximações históricas.

Este fosso é, aliás, muito freqüentemente exacerbado por alguns "não-cientistas", que jogam com uma falsa ingenuidade sobre sua ignorância, como este internauta do qual nós reproduzimos sucessivamente as respostas dirigidas àquele que se apresenta como "Biólogo, Suíço" e ao aluno do ENS (que nós citamos anteriormente).

De: @worldnet.fr>

Data: 01/12/1997

Esperando, eu continuo a comer as saladas de meu hortelão...

Sem me colocar muitas questões, somente lhes degustando.... ;-)

Comer saladas (ou comer em geral) não exige ter feito 6 anos de estudos em biologia.

Mas somente um pouco de bom senso.

Mas isso, é um pouco mais duro de aprender (o bom senso).

Porque ainda não está nos programas de escolas. (não ainda nos programas de escolas.)

Pode ser que em alguns anos...;-)

Mas bom, isso que eu disse, eu: eu não sou biólogo.... Somente amante das boas comidas (e de bons vinhos).

Cordialmente.

[Nome Sobrenome]

Rua, Campinas, 9: 47-68, 2003 
Esta mensagem é reveladora das representações que o público tem dos cientistas, representações que reatualizam os semas constitutivos da unidade lexical sábio. Parece, com efeito, que o mundo é partilhado entre aqueles que aprendem ou tem aprendido, os quais são desprovidos de toda outra capacidade e aqueles que são mantidos naturalmente de uma certa lógica e apreciam a boa carne.

De: @woldnet.fr>

Data: 04/12/1997

PS: de fato, você entendeu as informações, esta manhã: os Estados Unidos autorizam a irradiação da carne para eliminar as bactérias.... Depois o milho transgênico, os tomates imortais, eis o bife irradiado....

É isso, o Mac Donald De Luxo do ano 2000?

Bom apetite....

(Eu sei, eu sei, eu sou ignorante, etc, etc, .... )

$--$

[Nome Sobrenome]

Então, as trocas se tornam cáusticas, e a ignorância legítima de uns (aquela dos não especialistas) acaba remetendo os "científicos" aos próprios limites de seus conhecimentos:

De: @worlk.net

Data: 01/12/1997

Não respeitamos a seleção natural nesta nova espécie criada.

Em resumo, jogamos os aprendizes de feiticeiro nas costas dos consumidores, sem conhecer os efeitos a longo prazo.

Vocês, vocês continuam a comer seu M...ilho ;-) se fazendo todas as questões necessárias e suficientes para apreciar suas qualidades gustativas, dizem vocês. E eu, eu continuo a comer minha salada bio. 
É também a ocasião para alguns de colocar em causa as verdades científicas:

De: @wanadoo.fr>

Data: 06/12/1997

Atenção às certezas científicas, senhor biólogo. A teoria de Newton era sólida até que Einstein coloca seu grão de sal.

Assim, as numerosas questões deixadas sem resposta pelos cientistas são falhas nas quais a acusação dos cidadãos vem se alojar. Em definitivc, identidades eletrônicas. identidades clamadas e identidades discursivas formam uma massa enunciativa que nos parece não somente característica do suporte eletrônico Internet, mas também primordial para entender a dimensão das mensagens trocaóas.

\section{Conclusão}

Como vimos, as diferentes mensagens relativas aos CGM são a ocasião para muitos de afirmar sua identidade tanto quanto suas conviç̧ões, e isto com uma grande diversidade de meios. Ora, como cada um fala em seu próprio nome, fazendo-se defensor do ponto de vista que representa, os argumentos têm tendência a ser muito variados, talvez mais que nos debates conduzidos por jornalistas ou por pesquisadores entre eles. Segundo as competências e as informaçōes à disposição dos múltiplos interventores, diferentes domínios de referência são portanto mobilizados, como a política, o social, a economia, a ecologia, o caritativo, a ciência. Emergindo então vários planos de ancoragem da argumentação que podem ser aproximados daquilo que Luc Boltanski nomeia de "territórios". ${ }^{25}$

“Os "territórios" modelizados por Boltanki e Thévenot (1991) são definidos como "modos de legitimidade servindo de base às convençōes" sobre as quais se edificam as relações humanas. Segundo este sociólogo. "para agir em conjunto, os individuos devem implicitamente partilhar valores ou "convençōes". e cada um se apóia nos modos de "justificação" ou de legitimação, chamadas também "territórios". Os territórios denominados são seis: o território doméstico, o território civico, o território industrial, o território comercial, o território da opiniāo e o território inspirado. No corpus, são sobretudo os territórios cívico, industrial, comercial e o da op̣inião que são representados.

Rua. Campinas, 9: 47-68, 2003 
A complexidade dos pontos de vista se opera progressivamente. Mas, enriquecido de mensagem em mensagem, o debate sobre os OGM no seio do grupo "fr.sci.divers" resulta em uma certa relativização da ciência, embora a opinião pessoal, a consciência moral, a qualidade gustativa se afirmem como valores incontornáveis. Desdobrando-se, a discussão revela a multiplicidade das aspirações de cada um, aspirações liberadas quando da confrontação oratória, aspirações que são às vezes contraditórias entre elas. O científico se descobre gastrônomo, o cidadão mobiliza seus conhecimentos, numa mistura identitária que manifesta à sua maneira a complexidade de todo ser humano. Em relação a isso, podemos falar de uma "interiorização" do debate, já que a troca eletrônica leva à efervescência intelectual e afetiva de cada um.

Nessas condições, a argumentação utilizada parece muito distante de uma demonstração científica ponto por ponto (mesmo se tais passagens no crivo existam no fr.sci.divers). Todos os universos de referência têm um peso igual, sem que a esfera do científico seja privilegiada. Ora, os modos de legitimação não têm forçosamente valor de provas, e podemos nos perguntar se os diferentes universos de referência não são tanto mais facilmente convocados quanto a explicação científica encontra, com os OGM, seus limites. ${ }^{26}$

As interrogações apaixonadas sobre os OGM revisitam todo um imaginário coletivo que elas retrabalham em discursos novos no seio dos quais o indivíduo se afirma em toda sua complexidade social e psicológica.

Tradução: Cristiane P. Dias

Résumé

Le groupe de discussions "fr.sci.divers" a commencé un débat sur Internet en novembre de 1997. Il s'agit d'un débat autour de la question du maïs transgénique et des organismes génétiquement modifiés (OGM). Le corpus analysé dans cet article est extrait des messages échangés sur ce groupe, dans lequel le débat est centrée sur des événements politico-scientifiques et sur la science en général. L'analyse considère les "places énonciatives" construits dans le discours des internautes, lequels sons définis pour les auteurs du texte a partir des deux "communautés discursives": celui des spécialistes e celui des non-spécialistes.

26 Sobre a questāo dos conhecimentos a seus limites e da apresentação destes limites nos medias, nós remetemos à F. Mourlhon-Dallies (1999). 


\section{Referências bibliográficas:}

BEACCO J.-C. Les genres textuels dans l'analyse du discours: écriture légitime et communautés translangagières. In: Langages n. 105. Paris: Larousse, 1992.

BOLTANSKI L.: THEVENOT, L. De la justification. Paris: Gallimard, 1991.

CUSIN-BERCHE F. Curriel et genres discursif. In: Internet, communication et langue française. Paris: Hermès Sciences Publication, 1999.

GENETTE G. Palimpsestes. Seuil: Paris, 1982.

MOIRAND, S. Dialogisme et circulation des savoirs... In: Cabasino, F. (dir.). Du dialogisme au polylogue. Approches linguistiques, socio-pragmatiques, littéraires, actes du 3e colloque international DoRiF - Universita, Rome, octobre 1997. Rome: CISU, 1998.

MOIRAND, S. Les dimensions dialogiques d'une catégorie discursive: l'explication. Finlande: Université Turku, 1999.

MOURLHON-DALLIES, F. (astronomie dans les médias)

MOURLHON-DALLIES, F.; COLIN J.-Y., Les rituels énonciatifs des réseaux informatiques entre scientifiques. In: Les Enjeux des Discours Spécialisés. Carnets du Cediscor n 3, Paris: Presses de la Sorbonne-Nouvelle, 1995, pp. 161-172.

MOURLHON-DALLIES, F.; COLIN J.-Y., Des didascalies sur Internet? In: Internet, communication et langue française. Paris: Hermès Sciences Publication, 1999.

PERELMAN, C.; OLBRECHTS-TYTECAL. Traité de l'argumentation. Bruxelles: Editions de L'Université de Bruxelles, 1992,

“Agir et vivre en commun", entrevista com Luc Boltanski, revista Sciences humaines, número hors série n 5, mai-juin 1994, pp.13 a 15. 